\title{
Methodology for the design of a thermal energy storage module for a solar tunnel dryer using phase change materials (PCM)
}

\section{Metodología para el diseño de un módulo de acumulación térmica usando materiales de cambio de fase (PCM) para un secador solar de túnel}

\author{
Mario Escobar-Ochoa ${ }^{1}$, Sandra Cuervo-Andrade ${ }^{2}$, Sonia Rincon-Prat ${ }^{3}$
}

\begin{abstract}
${ }^{1}$ Grupo de Investigación en Biomasa y Optimización Térmica de Procesos - BIOT, Facultad de Ingeniería, Departamento de Ingeniería Mecánica y Mecatrónica, Universidad Nacional de Colombia - sede Bogotá, Colombia. Email: maaescobaroc@unal.edu.co

${ }^{2}$ Grupo de Investigación en Desarrollo Tecnológico, Mecatrónica y Agroindustria- GiDeTechMa y Grupo de Investigación en Biomasa y Optimización Térmica de Procesos - BIOT, Facultad de Ingeniería Mecánica, Universidad Pontificia Bolivariana - seccional Bucaramanga, Colombia. Email: sandra.cuervo@upb.edu.co

${ }^{3}$ Grupo de Investigación en Biomasa y Optimización Térmica de Procesos - BIOT, Facultad de Ingeniería, Departamento de Ingeniería Mecánica y Mecatrónica, Universidad Nacional de Colombia - sede Bogotá, Colombia. Email: slrinconp@unal.edu.co
\end{abstract}

RECEIVED: February 28, 2016. ACCEPTED: May 27, 2017. FINAL VERSION: October 25, 2017.

\begin{abstract}
The increasing interest in renewable energy has opened an opportunity to apply this technology in the industry and domestic sector. However, in solar-based systems, limitations associated with the intermittent energy delivery can cause unstable performance and unreliable designs. Weather fluctuations, such as wind speed and appearance of clouds, are considered the principal factors that contribute to the instability in the amount of energy available. In the agriculture, for instance, the use of thermal solar energy applied to dryer systems is highly desirable since the process is energetically very intensive. Therefore, it is feasible to design dryer devices for agricultural products, with important economic returns due to energy savings and the value added to the materials processed. Thus, the energy performance of systems that operate with solar thermal energy can be improved by introducing an energy accumulation system based on the use of phase change materials (PCM). The detailed methodology for the design of a thermal energy accumulation system for a tunnel dryer type Hohenheim for agricultural products is presented. As PCM, paraffin is chosen because its melting temperature is near $60{ }^{\circ} \mathrm{C}$, which is an appropriate value for the drying temperature of this kind of products. The theoretical calculations show that the value of the surface temperature has an important influence on phase change calculations and the total mass of PCM required in the system. On the other hand, the heat transfer is dominated by the external heat transfer in the air. Additionally, the tube diameter significantly affects the phase change time. The results obtained are important and make a significant contribution to the knowledge required for implementations of similar systems, since little has been explored in this field in regions where the weather conditions are suitable to unexpected changes. The design should be implemented in an experimental prototype of Hohenheim dryer and its performance is to be determined based on measurement of the energy change of the drying air.
\end{abstract}

KEYWORDS: Renewable energy; solar dryer; PCM; heat transfer. 


\section{RESUMEN}

El creciente interés en las energías renovables ha abierto una oportunidad para aplicar esta tecnología en la industria y el sector nacional. Sin embargo, en sistemas basados en energía solar, las limitaciones asociadas con la entrega de energía intermitente pueden causar un rendimiento inestable y diseños poco confiables. Las fluctuaciones climáticas, como la velocidad del viento y la apariencia de las nubes, se consideran los principales factores que contribuyen a la inestabilidad en la cantidad de energía disponible. En la agricultura, por ejemplo, el uso de la energía solar térmica aplicada a los sistemas de secado es altamente deseable ya que el proceso es energéticamente intensivo. Por lo tanto, es factible diseñar dispositivos de secado para productos agrícolas, con retornos económicos importantes debido al ahorro de energía y al valor agregado de los materiales procesados. Por lo tanto, el rendimiento energético de los sistemas que funcionan con energía solar térmica se puede mejorar mediante la introducción de un sistema de acumulación de energía basado en el uso de materiales de cambio de fase (PCM). Se presenta la metodología detallada para el diseño de un sistema de acumulación de energía térmica para un secador de túnel tipo Hohenheim para productos agrícolas. Como PCM, se elige parafina porque su temperatura de fusión es cercana a $60^{\circ} \mathrm{C}$, que es un valor apropiado para la temperatura de secado de este tipo de productos. Los cálculos teóricos muestran que el valor de la temperatura superficial tiene una influencia importante en los cálculos de cambio de fase y la masa total de PCM requerida en el sistema. Por otro lado, la transferencia de calor está dominada por la transferencia de calor externa en el aire. Además, el diámetro del tubo afecta significativamente el tiempo de cambio de fase. Los resultados obtenidos son importantes y aportan una contribución significativa al conocimiento requerido para implementaciones de sistemas similares, ya que se ha explorado poco en este campo en regiones donde las condiciones climáticas son adecuadas para cambios inesperados. El diseño debe implementarse en un prototipo experimental de secador Hohenheim y su rendimiento debe determinarse en función de la medición del cambio de energía del aire de secado.

PALABRAS CLAVE: Energía renovable; secador solar; PCM; transferencia de calor.

\section{INTRODUCTION}

The use of direct sun energy as renewable source in the industrial and domestic sector is limited due to its intermittent delivery. Particularly in the tropical region the availability of light hours is greater compared to the areas between the Arctic and Antarctic polar circles and the Tropics of Cancer and Capricorn. This favors the use of devices powered by this type of energy. Therefore, it is necessary to know the potential of renewable energy sources in the region, to make a good design process in projects related to this type of technologies $[21,22]$.

However, weather fluctuations (winds, clouds, etc.) cause variation in the amount of energy entering the devices. For this reason, mechanisms have been proposed to improve the conditions of stability and reliability of solar based systems. Such is the case of the use of thermal energy accumulation systems, using phase change materials (PCM), applied to devices that operate using solar thermal energy. Current research is aimed at comparing different types of PCM, determining the most appropriate depending on the application that is required. The most common uses, taking advantage of solar thermal energy can be found in applications for heating enclosures or swimming pools, water heaters or for dehydrating products $[1,2,3]$.

In the value chain for agricultural products, drying is the process with the highest energy requirement. For that reason, the implementation of dryers that use solar thermal energy has advantages, such as energy savings and reduction of production costs, together with increase in the value added of the products and reduction in product losses for farmers. In developing countries product losses can account for $30 \%$ to $40 \%$ of harvested material [4].

The main advantage of thermal energy accumulation systems using PCM in drying applications, compared with sensible heat accumulation, is that it is possible to maintain a constant temperature inside the drying chamber during energy delivering by phase change.

In the present work, the methodology of design of a thermal energy accumulation system for a Hohenheim type solar tunnel dryer for aromatic plants is presented.

The methodology includes the analysis of the heat transfer phenomena involving natural convection during phase change in the PCM and forced convection in the drying air. Paraffin is used as PCM as it has a melting temperature of $60^{\circ} \mathrm{C}$ which is in the appropriate range for the drying of aromatic plants. Other factors such as cost, availability and safety were also considered. The modified tunnel dryer, has a modular design consisting of three main parts: the collector, the accumulation system and the drying chamber. The designed accumulation system consists of a cross flow heat exchanger. The PCM is located inside copper tubes that are located perpendicular to the direction of the air flow. It was observed that the surface temperature of the tube 
has an important effect on the phase change time and on the total mass of PCM required in the system. On the other hand, a greater thermal resistance is presented in the heat transfer process by external convection, compared to the internal one. The developed methodology and the results obtained are important and make a significant contribution to the knowledge for possible implementations of similar systems since little has been explored in this field in the tropical region.

\section{INITIAL CONSIDERATION}

The energy accumulation module is designed to be placed in a Hohenheim-type tunnel dryer between the collector and the drying chamber. The basic configuration of this type of dryer can be found elsewhere $[5,6,7,8,9]$. The drying air is forced to flow through the dryer by means of fans located at the initial part of the collector. In the collector, the drying air is heated and then is conducted through the accumulation system and finally through the drying chamber.

The accumulation system consists of copper tubes in a tube bank arrangement forming a cross-flow heat exchanger. In the solar collector, the energy coming from the sun is captured by means of radiation heat transfer in a black surface and then transferred through convection to the drying air. When a suitable level of radiation is available, air flows through the system and is heated at a higher temperature than the melting temperature of the paraffin. Then by passing the accumulation system the paraffin inside the tubes undergoes melting. The design of the heat exchanger requires the quantification of the heat transfer phenomena that occur inside the tubes (natural convection with phase change) and outside of them (external forced convection). For the calculations following assumptions are made:

- The design is performed for the option in which the system is accumulating energy, the PCM undergoes a melting process. After having designed the system, its behavior during solidification is analyzed.

- No overheating of the melted PCM or sub cooling of the solidified PCM is considered.

- The inlet temperature and mass flow of the air in the heat exchanger is constant.

- Energy transferred in the system during phase change varies with time due to the continuous changing of the solid and melting fractions inside the tubes. For design purposes the heat transfer in the system is analyzed as a steady state process with average constant parameters.

- Heat losses in the system are negligible.

From the last assumption an energy balance in the module states that the energy delivered by the air is transferred to the phase change material during the phase change process. This quantity of energy is the parameter that enables to determine whether the heat exchanger meets the established requirement for desired heat transfer rate $\left(\dot{Q}_{\mathrm{d}}\right)$ or not. The desired heat transfer rate is calculated from the temperature change in the air based on an input temperature in the tube bank of $\left(T_{0}=65^{\circ} \mathrm{C}\right)$ (temperature reachable at the collector outlet) and the desired outlet temperature $T_{\mathrm{F}}=60{ }^{\circ} \mathrm{C}$ (suitable drying temperature for agricultural products [11]) and can be calculated using (Equation 1).

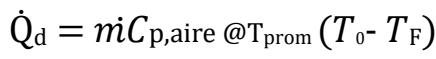

The air velocity is set at $u=0.8 \mathrm{~m} \mathrm{~s}^{-1}$, this value lies in the higher range used in this type of dryers [3]. Higher velocities mean higher air mass flows and consequently the heat transfer requirement to reach the desired temperature is higher, the module is than designed for this work condition. The thermo physical properties of air are calculated at the average temperature $\left(\mathrm{T}_{\text {prom }}\right)$ between inlet $\left(T_{0}\right)$ and outlet $\left(T_{\mathrm{F}}\right)$.

For calculation purposes, all tubes were assumed to have the same length of $1 \mathrm{~m}$ corresponding to the width of the tunnel dryer. However, the tubes have different dimensions, since this system is incorporated in a module with the same geometry of the solar dryer in gable roof disposition. This can be seen in Figure 7 were the length of each tube decreases with the vertical distance. The final design considers these variations by increasing the number of rows at the end of the assembly in a way that the heat transfer area $A_{\mathrm{T}}$ and the mass of PCM correspond to the calculated values.

\section{METHODOLOGY}

The design methodology comprises four main stages. Stage one includes heat transfer through phase change inside the tubes. The paraffin properties required to perform the calculations are summarized in Annex A1. The analysis of this zone allows the calculation of the convection heat transfer coefficient on the internal side $h_{\text {int }}$ and the required minimum mass of PCM required. Stage two corresponds to the geometric sizing of the system, which is based on the required minimum mass of PCM and the available space in the cross section of the tunnel. The dimensioning allows determining the convection heat transfer coefficient in the external side $h_{\text {ext }}$ of the tubes. The calculation procedures of $h_{\text {in }}$ and $h_{\text {ext }}$ requires the knowledge of the surface temperature of the tubes $\left(T_{\mathrm{s}}\right)$. As this parameter is not known a first estimation is made. With $h_{\text {int }}$ and $h_{\text {ext }}$, the total heat transfer coefficient of the exchanger $U$ is determined. 
Stage three, includes verifying if the proposed design meets the requirement given by the desired heat $\dot{Q}_{d}$ This is done by applying the Number of Transfer Units (NTU) method for the design of heat exchangers. The effectiveness of the heat exchanger and the actual heat transfer $\dot{\mathrm{Q}}_{\text {real }}$, which must be greater than or equal to $\dot{\mathrm{Q}}_{\mathrm{d}}$, were calculated. In case of not fulfilling the condition, a geometric resizing of the system was carried out. When the heat requirement is fulfilled, the actual surface temperature $T_{\mathrm{s}}$ of the tubes and the final temperature $T_{\mathrm{F}}$ of the air are calculated in stage four. Finally, in stage five, the design is consolidated.

\subsection{Analysis of heat transfer inside the tubes}

For the heat transfer analysis inside the tubes the correlations proposed by Bareiss et al. [8] are used. They developed expressions for an average $\mathrm{Nu}_{\text {int }}$ (Equation 2) and an average dimensionless melting time $\tau_{a}$ (Equation 3) for a PCM inside a circular enclosure. The average value of $h_{\text {int }}$ is calculated from $\mathrm{Nu}_{\text {int }}$ as $h_{\text {int }}=\mathrm{Nu}_{\text {int }}$ $k_{P C M} / r_{\text {int }}$. Using (Equation 4) together with (Equation 5 and 6) the required minimum mass of PCM in the system can be determined.

$\tau_{a}=2.49\left(\frac{\text { Ste }}{\mathrm{PrAr}}\right)^{0.25} \rho^{\prime-0.75}\left(\frac{1}{1+\mathrm{C}}\right)$

$\mathrm{N} u_{\text {int }}=0.2\left(\frac{\operatorname{Pr} \text { Ar }}{\text { Ste }}\right)^{0.25} \rho^{-0.75}(1+\mathrm{C})$

$\mathrm{Fo}=\left(\frac{\tau_{a}}{\text { Ste }}\right)$

$\mathrm{Fo}=\left(\frac{a t}{r_{\text {int }}^{2}}\right) \rightarrow t=\left(\frac{\text { Fo }^{2}}{a}\right)$

$\dot{\mathrm{Q}}_{\mathrm{d}}=\frac{m_{\mathrm{PCM}}}{t} \lambda \rightarrow m_{\mathrm{PCM}}=\left(\frac{\dot{\mathrm{Q}}_{\mathrm{d}} t}{\lambda}\right)$

\subsection{External heat transfer through the tubes}

The analysis of the heat transfer on the external side of the heat exchanger is based on the method proposed by Zukauskas presented by Cengel [9]. For a staggered configuration Nuext can be estimated according to (Equation 7). $\operatorname{Re}_{D}$ is calculated using the maximum air speed in the arrangement. $h_{\text {ext }}$ is determined from $\mathrm{Nu}_{\text {ext }}$ as $h_{\text {ext }}=\mathrm{Nu}_{\text {ext }} k_{\mathrm{a}} / \mathrm{D}_{\text {ext }}$. The overall heat transfer coefficient of the exchanger (U) is calculated according to (Equation 8).

$$
\begin{gathered}
\mathrm{N} u_{\text {ext }}=0.35\left(\frac{\mathrm{S}_{\mathrm{T}}}{\mathrm{S}_{\mathrm{L}}}\right)^{0.2} \operatorname{Re}_{D}^{0.6} \operatorname{Pr}^{0.36}\left(\frac{\mathrm{Pr}}{\mathrm{Pr}_{S}}\right)^{0.25} \\
\frac{1}{U}=\frac{1}{h_{\text {ext }}}+\frac{1}{h_{\text {int }}}
\end{gathered}
$$

\subsection{Determination of the heat capacity of the module}

Using the calculated external and internal heat transfer coefficients, the heat transfer capacity of the module is determined using the method of Number of Transfer Units (NTU-Method) [11, 10]. The actual heat transfer in the module is calculated according to (Equation 9 to 11). The maximal heat transfer $\dot{\mathrm{Q}}_{\text {máx }}$ is calculated from the maximum temperature difference and the heat capacity of the air $\left(C_{\min }\right)$.

In the case that $\dot{\mathrm{Q}}_{\text {real }}<\dot{\mathrm{Q}}_{\mathrm{d}}$ it is necessary to perform a resizing process to increase $\dot{\mathrm{Q}}_{\text {real }}$.

3.4. Determination of the actual tube surface temperature $\left(T_{s}\right)$ and air exit temperature $\left(T_{F}\right)$

The procedure for calculating the actual tube surface temperature $\left(\mathrm{T}_{\mathrm{s}}\right)$ was to relate the $\dot{\mathrm{Q}}_{\text {real }}$ to find the phase change time by (Equation 6). Initially the assumed $\mathrm{T}_{\mathrm{s}}$ is taken to find the mass of PCM $\left(m_{\mathrm{PCM}}\right)$. That calculated time is compared to the time that is calculated when the phenomenon of heat transfer into the tubes is involved. So, the actual tube surface temperature $\left(T_{s}\right)$ is when this iterative process is performed, and equalities are achieved at the time of phase change.

$T_{\mathrm{F}}$ is calculated using Equation 9 [6] from an energy balance of the drying air.

$T_{F}=T_{0}-\frac{\dot{Q}_{\text {real }}}{\dot{m} C_{\text {paire }}}$

\section{RESULTS AND DISCUSSION}

Table 1 show the results of the heat transfer analysis inside and outside the tubes respectively when using a first set of given conditions. Table 2, shows the results of the operation of the heat exchanger.

For the analysis of the external heat transfer the staggered configuration was used as it allows a higher turbulence in the air increasing the heat transfer in the system. The distances between tube axes $\left(S_{T}\right.$ and $S_{L}$ in in Table 3 ) are initially fixed as two times the diameter of the tube. Table 3 presents the main dimensions of the tube bank. 
Table 1. Calculated heat transfer parameters.

\begin{tabular}{|l|l|}
\hline Parameters & Value \\
\hline Internal heat transfer & 0.01166 \\
\hline$\tau_{\mathrm{a}}[-]$ & 48.77 \\
\hline $\mathrm{Nu}_{\text {int }[-]}$ & 561.35 \\
\hline$h_{\text {int }}\left[W m^{-2} \mathrm{~K}^{-1}\right]$ & 64.74 \\
\hline$m_{\mathrm{pcm}, \min }[\mathrm{Kg}]$ & 1.77 \\
\hline Fo [-] & 126.80 \\
\hline$t[\min ]$ & \\
\hline External heat transfer & 41.16 \\
\hline Nuext[-] & 28.22 \\
\hline$h_{\text {ext }}\left[W m^{-2} \mathrm{~K}^{-1}\right]$ & \\
\hline
\end{tabular}

Source: Own elaboration.

$$
\begin{aligned}
& \dot{\mathrm{Q}}_{\text {real }}=\varepsilon \dot{\mathrm{Q}}_{\text {máx }} \\
& \varepsilon=1-\exp (-\mathrm{NTU}) \\
& \mathrm{NTU}=\mathrm{U} \mathrm{A}_{\mathrm{T}} / C_{\text {mín }}
\end{aligned}
$$

Table 2. Calculated parameters of the heat exchanger.

\begin{tabular}{|l|l|}
\hline Parameters & Value \\
\hline $\mathrm{U}[\mathrm{W} \mathrm{m-2} \mathrm{K-1]}$ & 26.87 \\
\hline$\Delta T_{\text {máx }}\left[{ }^{\circ} \mathrm{C}\right]$ & 5.50 \\
\hline$\dot{\mathrm{Q}}_{\text {máx }}[\mathrm{W}]$ & 1769.07 \\
\hline $\mathrm{NTU}[-]$ & 0.79 \\
\hline$\varepsilon[-]$ & 0.55 \\
\hline$\dot{\mathrm{Q}}_{\text {real }}[\mathrm{W}]$ & 966.83 \\
\hline$\dot{\mathrm{Q}}_{\mathrm{d}}[\mathrm{W}]$ & 1608.24 \\
\hline
\end{tabular}

As can be seen from Table 2 the calculated value of $\dot{Q}_{\text {real }}$ is lower than $\dot{Q}_{d}$. Therefore, it is necessary to perform a resizing of the system aiming to increase the value of $\dot{Q}_{\text {real }}$. As shown in (Equation 10) this value is a function of the effectiveness $\varepsilon$ and the maximum heat $\dot{Q}_{\text {máx }}$.

The value of $\dot{Q}_{\text {máx }}$, for the present study, is considered constant, since it depends on $C_{\text {min }}$ that in turn depends on the specific heat of the air and its mass flow and $\Delta T_{\text {máx }}$ is a design parameter. To reach the desire value of $\dot{Q}_{d}=1$ 608.24 an effectiveness $\varepsilon$ of $90.90 \%$ should be needed, representing an increment of $63 \%$ from the initial value of $55,00 \%$. NTU must be then incremented from 0,79 to 2.377, calculated from (Equation 11). As shown in (Equation 12) the value of NTU can be increased by:

- Increasing the overall heat transfer coefficient U.

- Increasing the heat transfer area $A_{T}$.

- A simultaneously increase in $\mathrm{U}$ and $A_{T}$ (in case the increase of one of the two independently is not sufficient to achieve the expected NTU value).

Table 3. Configuration of the tube bank.

\begin{tabular}{|l|l|l|}
\hline Scheme & Parameters & Value \\
\hline \multirow{3}{*}{$\bigcirc$} & $\begin{array}{l}\text { Total mass of } \\
\text { PCM required in a } \\
\text { tube }\left(m_{\mathrm{PCM}, 1 \mathrm{t}}\right)[\mathrm{kg}]\end{array}$ & 0.90 \\
\cline { 2 - 3 } & Number of tubes & 73 \\
\cline { 2 - 3 } & $S_{\mathrm{T}}[\mathrm{m}]$ & 0.083 \\
\cline { 2 - 3 } & $A_{1}\left[\mathrm{~m}^{2}\right]$ & 0.083 \\
\hline$A_{\mathrm{T}}\left[\mathrm{m}^{2}\right]$ & 0.0413 \\
\cline { 2 - 3 } & $S_{\mathrm{L}}[\mathrm{m}]$ & 0.083 \\
\hline & $S_{\mathrm{D}}[\mathrm{m}]$ & 0.0923 \\
\cline { 2 - 3 } & $A_{\mathrm{D}}\left[\mathrm{m}^{2}\right]$ & 0.051 \\
\hline
\end{tabular}

Source: Own elaboration.

Source: Own elaboration.

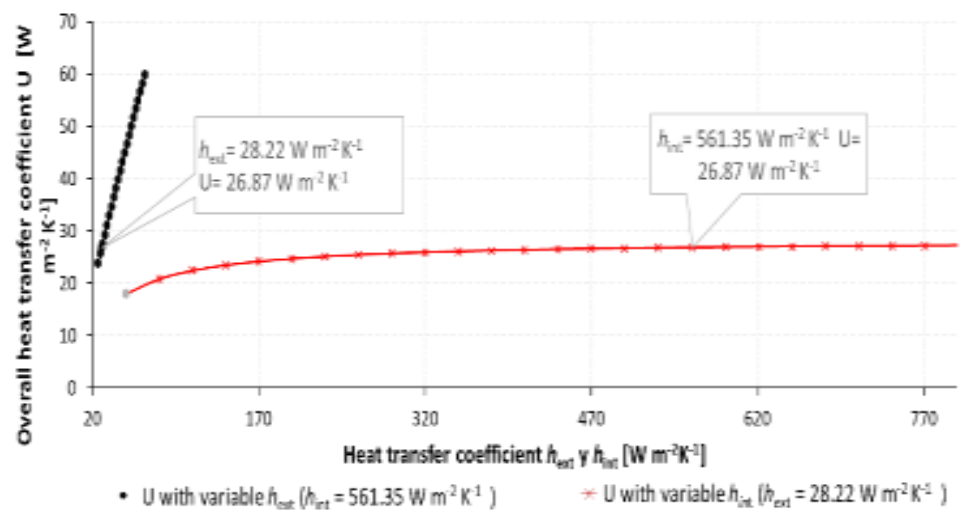

Figure 1. Variation of the overall heat transfer coefficient $U$ with respect to $h_{\text {ext }}$ and $h_{\text {int }}$.Source: Own elaboration. 
The overall heat transfer coefficient $\mathrm{U}$ depends on $h_{\text {int }}$ and $h_{\text {ext }}$. In Figure 1 the change of $\mathrm{U}$ is presented with a variation of $h_{\text {int }}$ (line with asterisks) keeping the value of $h_{\text {ext }}$ constant in $28.22 \mathrm{~W} \mathrm{~m}^{-2} \mathrm{~K}^{-1}$; and with a variation of $h_{\text {ext }}$ (line with circles) keeping the value of $h_{\text {int }}$ constant at $561.35 \mathrm{~W} \mathrm{~m}^{-2} \mathrm{~K}^{-1}$. It is clearly observed that the system is dominated by the external heat transfer. This behavior is expected because of the high value of the internal heat transfer coefficient, compared to the value of the external heat coefficient. Modifications tending to increase the value of $U$ should concentrate on improving the heat transfer from the external side.

An increase in $h_{\text {ext }}$ is reached with an increase in $\mathrm{Nu}_{\text {ext }}$ which is achieved by increasing $R e_{D}$ and making the ratio $S_{T} / S_{L}$ greater than 1 as expected from Equation 7 .
A decrease in $S_{T}$ and $S_{L}$ increases the maximum air velocity in the tube bundle making $R e_{D}$ higher.Figure 2 shows the variation of $h_{\text {ext }}$ with $S_{T} / S_{L}$. The variation is done by keeping the value of $S_{L}$ constant at 0.05159 , which corresponds to 2.5 times the radius of the tube $(0.0206 \mathrm{~m})$ varying the value of $S_{T}$ according to the desired ratio. This figure shows that with an increase in the ratio $S_{T} / S_{L}$ the $h_{\text {ext }}$ decreases considerably. This is because the decrease in the Reynolds number (indicated in the figure) caused by the increase in the distance $S_{T}$ has a greater effect on Equation 7 than the increase in that ratio. The pressure drop in the tube bank is determined by applying the relationship developed by Zukauskas et al. $[14,15]$. The calculated pressure drop is only $60 \mathrm{~Pa}$ for the most critical case in which $S_{T}$ and $S_{T}$ are low, so it is not considered a relevant issue when selecting the distances between tubes.

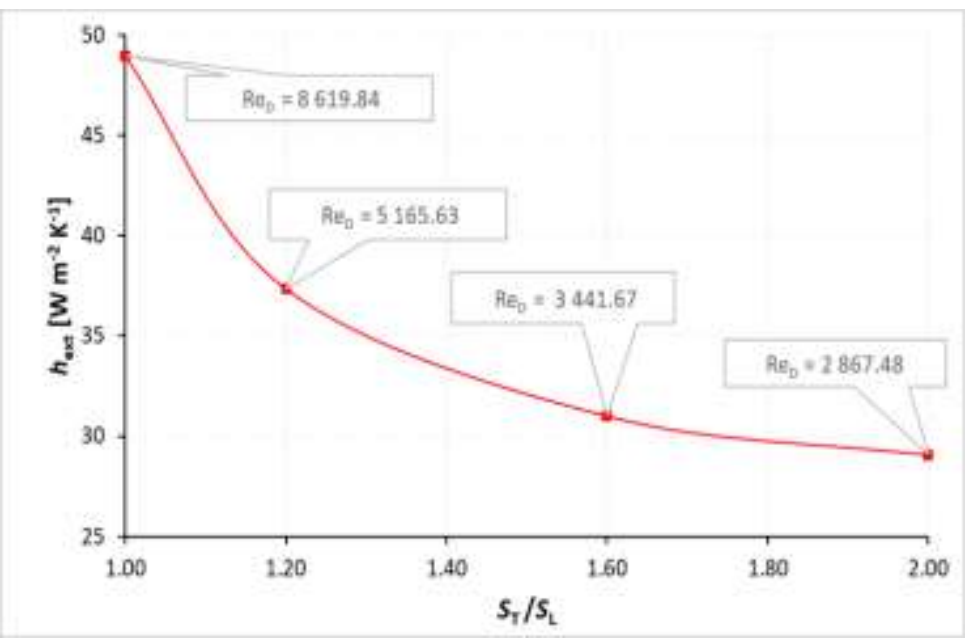

Figure 2. Variation of $h_{\text {ext }}$ with the relation $S_{T} / S_{L} . R e_{D}$ is included for selected values. Source: Own elaboration.

Figure 3 presents the results of $\mathrm{U}$ by $S_{T} / S_{L} 1.0$ and 1.2. The best option to implement in the design is $S_{T} / S_{L} 1.0$, with a distance between centers of $1.25 \mathrm{D}$, obtaining $\mathrm{U}=$ $44.99 \mathrm{~W} \mathrm{~m}^{-2} \mathrm{~K}^{-1}$ that corresponds to an increment of $59.71 \%$ when compared with the initial value.

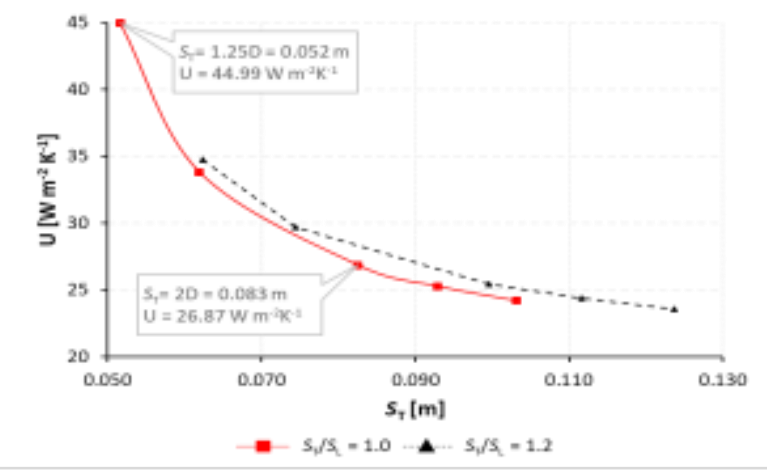

Figure 3. Overall heat transfer coefficient $U$ by $S_{T} / S_{L} 1.0$ and 1.2. Source: Own elaboration.
Another possibility to increase the value of $U$ is by changing the tube diameter. Two possibilities where studied maintaining a relation $S_{T}=S_{L}=1.25 \mathrm{D}$. This distance, was proposed by Holman [12]. The effect of varying the tube diameter affects both the inside and the outside heat transfer conditions of the tubes, so this is considered when calculating U. As can be seen in Figure 4 with an increment in tube diameter (these are the commercial ranges of pipelines) the overall heat transfer coefficient is considerably affected. Between $3 / 4$ and 1.5 in of commercial diameters. However, for pipes with a diameter between 2 and 4, there is no significant variation in the overall heat transfer coefficient, therefore, no account will be taken. 


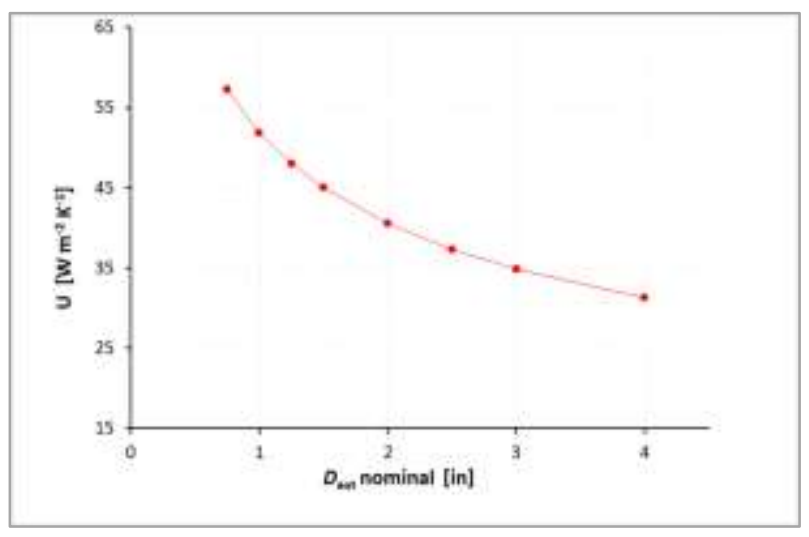

Figure 4. Behavior of $\mathrm{U}$ varying the nominal $D_{\text {ext }}$ of the copper tube. Source: Own elaboration.

Due to the increment of the cross section of the tubes, the phase change time increases as the radius becomes larger. Phase change time is an important design parameter as short phase change times mean short energetic autonomy of the system. For the present project $2 \mathrm{~h}$ autonomy is considered as acceptable. It was observed that diameters smaller than 1.5 in are not suitable for the design because they have a shorter phase change time. In turn, large diameters have a lower overall heat transfer coefficient value.

When performing the calculations again, with the nominal diameter of $1.5 \mathrm{in}, S_{T} / S_{L}$ ratio and $S_{T}$ distance; the new values are: $h_{\text {ext }}=48.91 \mathrm{~W} \mathrm{~m}^{-2} \mathrm{~K}^{-1}$, NTU $=1.32$, $\varepsilon=0.73, \dot{\mathrm{Q}}_{\text {real }}=1298.33 \mathrm{~W}$. Although, $\dot{\mathrm{Q}}_{\text {real }}$ approaches $\dot{\mathrm{Q}}_{\mathrm{d}}$, it is still below it.

Another improvement in NTU can be reached by increasing the heat transfer area $\mathrm{A}_{\mathrm{T}}$. Figure 5 presents the variation of NTU with $A_{T}$ between 9.47 and $12.45 \mathrm{~m}^{2}$, which is the range of area that can be handled in the system. As shown in Figure 5, the increment in NTU is not as effective as when increasing U. Moreover, the possibility of increasing the heat transfer area of the tubes is limited due to space considerations, structural problems that can be presented in the module due to excessive weight and increasing costs. Consequently, an increment in heat transfer area is not considered.

Table 4 presents a general summary of the resizing of the system. With these changes, the ratio of $\dot{\mathrm{Q}}_{\text {real }}$ and $\dot{\mathrm{Q}}_{\mathrm{d}}$ is $80.73 \%$. The value of $1298.33 \mathrm{~W}$ is the maximum achievable heat transfer in the system and is accepted for the final design. Finally, the Table 5 shows the actual values of $\mathrm{T}_{\mathrm{F}}$ and $\mathrm{T}_{S}$ compared with the values assumed initially.

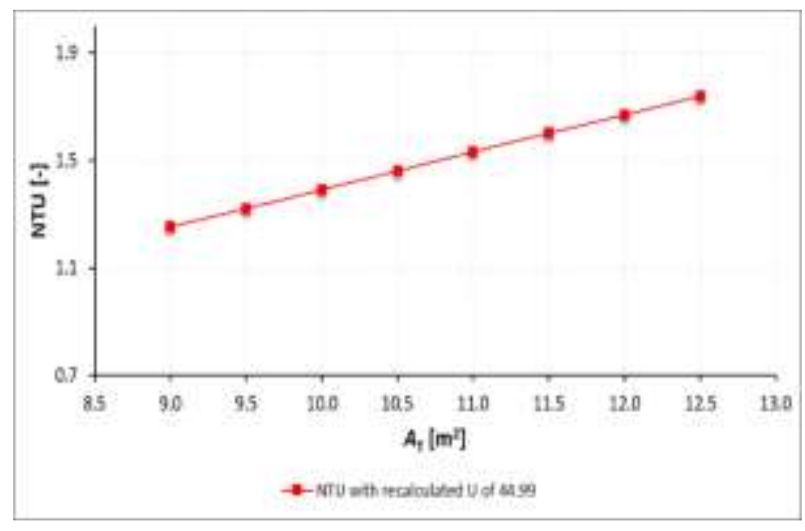

Figure 5. NTU behavior, modifying $A$ T. Source: Own elaboration.

Table 4. Design parameters recalculated with $S_{T}=S_{L}=1.25 \mathrm{D}$.

\begin{tabular}{|l|l|}
\hline Parameter & Value \\
\hline$C_{\text {mín }}\left[\mathrm{W} \mathrm{K}^{-1}\right]$ & 321.65 \\
\hline$\Delta T_{\text {máx }}\left[{ }^{\circ} \mathrm{C}\right]$ & 5.50 \\
\hline$\dot{\mathrm{Q}}_{\text {máx }}[\mathrm{W}]$ & 1769.07 \\
\hline $\mathrm{NTU}[-]$ & 1.32 \\
\hline$\varepsilon[-]$ & 0.73 \\
\hline$\dot{\mathrm{Q}}_{\text {real }}[\mathrm{W}]$ & \\
\hline
\end{tabular}

Source: Own elaboration.

Table 5. Assumed and calculated values of $T_{\mathrm{s}}$ and $T \mathrm{~F}$.

\begin{tabular}{|l|l|l|}
\hline Temperature & Assumed value & Calculated value \\
\hline $\mathrm{T}_{\mathrm{S}}\left[{ }^{\circ} \mathrm{C}\right]$ & 59.50 & 59.38 \\
\hline $\mathrm{T}_{\mathrm{F}}\left[{ }^{\circ} \mathrm{C}\right]$ & 60.00 & 60.96 \\
\hline
\end{tabular}

Source: Own elaboration.

With the calculated $T_{\mathrm{s}}\left(59.38^{\circ} \mathrm{C}\right)$ and the $T_{\mathrm{s}}$ assumed initially, Table 6 shows a comparison of parameters calculated from the point of view of the phenomenon of internal heat transfer in the tube. As can be seen in Equation 7, the incidence of $T_{\mathrm{s}}$ in the external phenomenon of heat transfer is only evident in the ratio of $\left(\operatorname{Pr} / \mathrm{Pr}_{s}\right)^{0.25}$, whereby it can be stated that the temperature of the surface, has no relevant impact on the external heat transfer. A different situation occurs in the internal side, where $T_{\text {s }}$ plays an important role when calculating the time of phase change and minimum mass of PCM. 
Table 6. Comparison of internal heat transfer parameters with calculated and assumed $\mathrm{T}_{\mathrm{s}}$

\begin{tabular}{|l|l|l|}
\hline $\begin{array}{l}\text { Parameters to } \\
\text { evaluate }\end{array}$ & $\begin{array}{l}\text { Value with } \boldsymbol{T}_{\mathrm{s}} \\
\text { assumed }(\mathbf{5 9 . 5 0} \\
\left.{ }^{\circ} \mathbf{C}\right)\end{array}$ & $\begin{array}{l}\text { Value with } \boldsymbol{T}_{\mathrm{s}} \\
\text { calculated } \\
\left(\mathbf{5 9 . 3 8}{ }^{\circ} \mathbf{C}\right)\end{array}$ \\
\hline $\begin{array}{l}\text { Dimensionless } \\
\text { time } \tau_{a}[-]\end{array}$ & 0.01166 & 0.01089 \\
\hline Nusselt Nu [-] & 48.77 & 52.23 \\
\hline $\begin{array}{l}\text { Minimum mass of } \\
\text { PCM [kg] }\end{array}$ & 64.74 & 80.19 \\
\hline Fourier Fo [-] & 1.77 & 2.19 \\
\hline $\begin{array}{l}\text { Phase change time } t \\
\text { [min] }\end{array}$ & 126.80 & 157.07 \\
\hline
\end{tabular}

Source: Own elaboration.

\section{FINAL DESIGN}

Figure 6 shows the final configuration of the thermal storage module. As can be seen in figure 7a, the length of the tubes varies with the vertical distance, therefore, it is necessary to attach more rows in the module, to maintain the calculated heat transfer area of $9.47 \mathrm{~m}^{2}$. Figure $7 \mathrm{~b}$ shows the configuration of the rows along the accumulation module. This final design will be implemented in a prototype of a Hohenheim-type tunnel dryer to evaluate its performance experimentally.

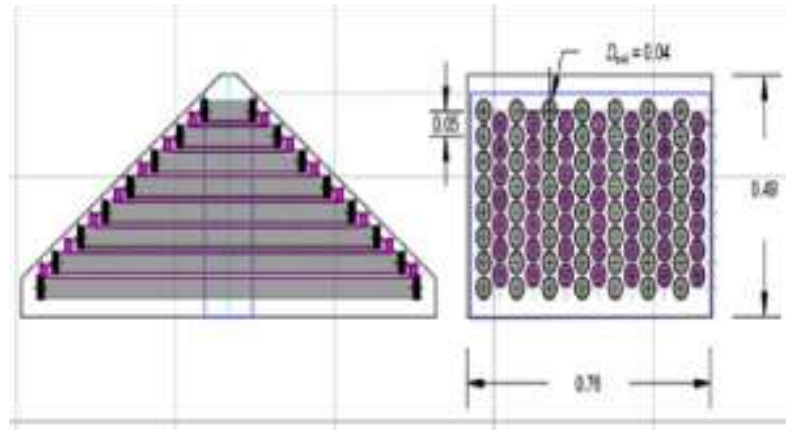

(a)

(b)

Figure 6. Final configuration of the thermal storage module. (a) Cross section (b) Longitudinal section. Measures in meters. Source: Own elaboration.

\section{PERFORMANCE OF THE SYSTEM AT SOLIDIFICATION CONDITIONS}

Using the above design, the performance of the thermal storage module during solidification conditions is analyzed. In this case the inlet temperature is lower than the phase change temperature of the paraffin. It is assumed that the PCM is in liquid phase at the phase change temperature and it is instantly subjected to the air temperature. For the analysis, only the latent heat is considered. Applying the NTU-Method the actual heat transfer in the system is calculated and presented in Table 7 for different air temperatures.

Table 7. Results applying the NTU-Method.

\begin{tabular}{|l|l|l|l|l|}
\hline$T_{0}\left[{ }^{\circ} \mathbf{C}\right]$ & \multicolumn{1}{|c|}{$\dot{\mathbf{Q}}_{\text {máx }}$} & $C_{\text {mín }}$ & NTU & $\varepsilon$ \\
\hline 20 & 13461.21 & 345.16 & 1.242 & 0.7112 \\
\hline 25 & 11665.68 & 343.11 & 1.245 & 0.7119 \\
\hline 30 & 9895.10 & 341.21 & 1.251 & 0.7139 \\
\hline 35 & 8108.96 & 337.87 & 1.259 & 0.7162 \\
\hline 40 & 6388.77 & 336.25 & 1.265 & 0.7177 \\
\hline 45 & 4641.51 & 331.54 & 1.277 & 0.7213 \\
\hline 50 & 2968.68 & 329.85 & 1.282 & 0.7225 \\
\hline 55 & 1310.23 & 327.56 & 1.286 & 0.7239 \\
\hline
\end{tabular}

Source: Own elaboration.

Analyzing the behavior of the system, varying $T_{0}$, in terms of heat transfer, there is no significant variation, so that $U$ and NTU are maintained in similar values. However, what makes difference, is the difference in temperature that is reflected in the calculation of $\dot{\mathrm{Q}}_{\text {máx }}$ and $\dot{\mathrm{Q}}_{\text {real }}$. In these parameters if a change is observed, so they are in function of the temperature difference.

Figure 7 shows the variation of $T_{\mathrm{F}}$ and $\dot{\mathrm{Q}}_{\text {real }}$ with $T_{0}$. As the effectiveness remains almost constant $\dot{\mathrm{Q}}_{\text {real }}$ is proportional to $\dot{\mathrm{Q}}_{\text {máx }}$ and consequently to $T_{\mathrm{F} \text { - }}$ The minimum outlet temperature for an inlet temperature of $20^{\circ} \mathrm{C}$ is $48^{\circ} \mathrm{C}$ which is an acceptable drying temperature. Furthermore, at higher heat transfer rates lower phase change times are expected, since the total amount of energy remains constant as it depends on the mass of PCM.

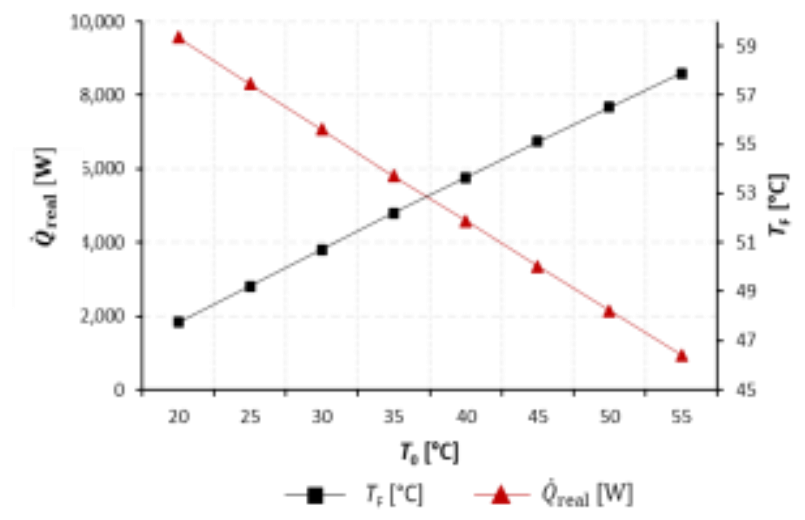

Figure 7. Behavior of the system, $\dot{\mathrm{Q}}_{\text {real }}$ and $T_{\mathrm{F}}$ varying $T_{0}$. Source: Own elaboration. 
The phase change time can be calculated from Equation 13. $\dot{Q}_{\text {total }}$ is determined as the total energy that the mass of PCM delivers during solidification (for the purposes of this analysis the sensible heat is not considered).

$t=\frac{\dot{\mathrm{Q}}_{\text {total }}}{\dot{\mathrm{Q}}_{\text {real }}}$
As shown in Figure 8 as $\dot{Q}_{\text {real }}$ decreases the phase change time increases considerably. Thus, if the temperature in the system drops instantaneously from phase change temperature to ambient temperature $\left(20^{\circ} \mathrm{C}\right)$ the system has still autonomy of approximately $30 \mathrm{~min}$. If the temperature remains at $55^{\circ} \mathrm{C}$ the autonomy would rise to more than $4.6 \mathrm{~h}$.

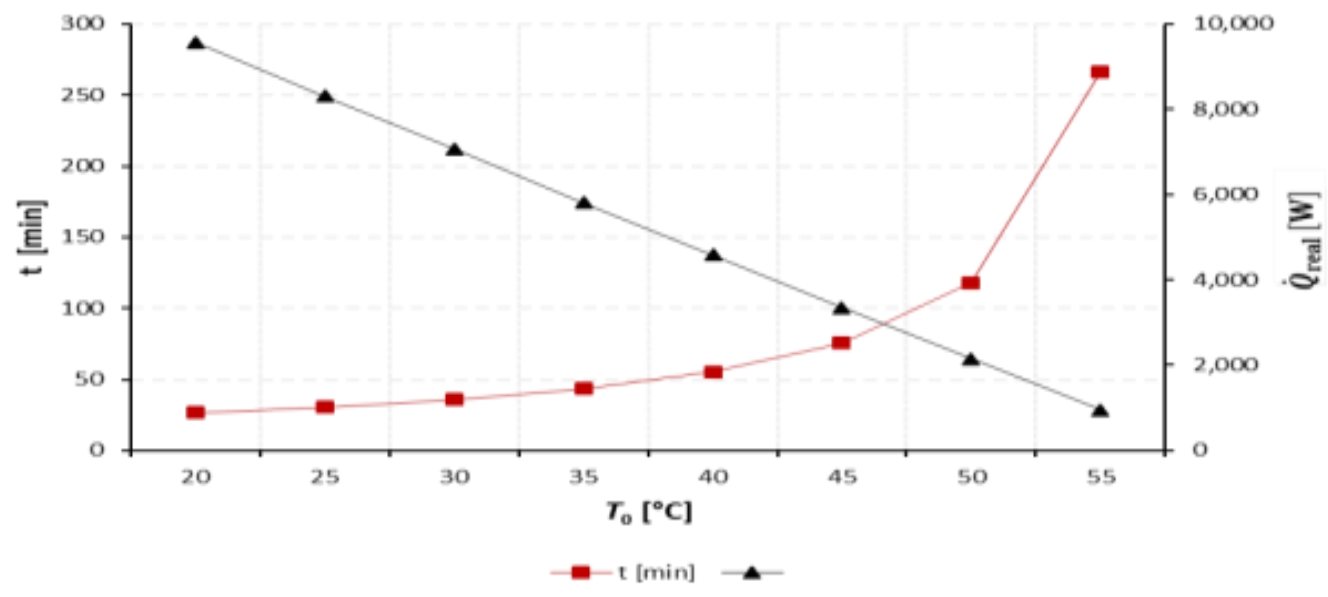

Figure 8. Variation of phase change time $t$ [min]with $T_{0}$. Source: Own elaboration.

\section{CONCLUSIONS}

One of the main disadvantages of implementing drying devices using solar energy is the intermittent energy supply due to weather fluctuations. This can be reduced with the implementation of thermal energy storage systems using PCM materials.

The developed methodology for the design of an energy storage module consisting of a cross flow heat exchanger in which the PCM is located inside the tubes can be easily implemented in the design of modules with different conditions of temperature and air flow. The analysis of the heat transfer phenomena showed that the system is controlled by the external heat transfer in the air which is strongly affected by the air speed in the system.

The heat transfer during phase change inside the tubes is important in determining the melting time which depends strongly on the surface temperature and the tube diameter. Melting times from $30 \mathrm{~min}$ to $4.6 \mathrm{~h}$ can be achieved depending on the outside temperature.

\section{ACKNOWLEDGMENTS}

The authors gratefully acknowledge the financial support by the Vicerrectoría de Investigación of the Universidad
Nacional de Colombia (Hermes 19926) and the Universidad Pontificia Bolivariana of Bucaramanga.

\section{Appendices \\ Appendix A}

Table A1. Thermophysical Properties of Semi-Defined Paraffin

\begin{tabular}{|l|l|l|}
\hline Properties & Value & References \\
\hline$T_{\mathrm{PCM}}\left[{ }^{\circ} \mathrm{C}\right]$ & 59.00 & {$[13]$} \\
\hline$C_{\mathrm{p}, \mathrm{sól}}\left[\mathrm{J} \mathrm{kg}^{-1} \mathrm{~K}^{-1}\right]$ & 59000.00 & {$[14]$} \\
\hline$C_{\mathrm{p}, \text { líq }}\left[\mathrm{J} \mathrm{kg}^{-1} \mathrm{~K}^{-1}\right]$ & 2490.00 & {$[14]$} \\
\hline$\rho_{\text {sól }}\left[\mathrm{kg} \mathrm{m}^{-3}\right]$ & 893.00 & {$[14]$} \\
\hline$\rho_{\text {líq }}\left[\mathrm{kg} \mathrm{m}^{-3}\right]$ & 782.00 & {$[14]$} \\
\hline$\rho^{\prime}$ & 0.88 & {$[15]$} \\
\hline$k_{\mathrm{PCM}}\left[\mathrm{W} \mathrm{m}^{-1} \mathrm{~K}^{-1}\right]$ & 0.22 & {$[16]$} \\
\hline$\lambda\left[\mathrm{J} \mathrm{kg}^{-1}\right]$ & 189,000 & {$[14]$} \\
\hline$\alpha_{\text {líq }}\left[\mathrm{m}^{2} \mathrm{~s}^{-1}\right]$ & $8.50 . \mathrm{E}-08$ & {$[17]$} \\
\hline$\beta\left[\mathrm{K}^{-1}\right]$ & $7.78 . \mathrm{E}-04$ & {$[18]$} \\
\hline$v\left[\mathrm{~m}^{2} \mathrm{~s}^{-1}\right]$ & $5.23 . \mathrm{E}-06$ & {$[18]$} \\
\hline$\mu\left[\mathrm{kg} \mathrm{m}^{-1} \mathrm{~s}^{-1}\right]$ & $4.84 . \mathrm{E}-03$ & {$[18]$} \\
\hline
\end{tabular}


Greek alphabet

\begin{tabular}{|c|c|c|c|}
\hline Symbol & Definition & Symbol & Definition \\
\hline$\alpha_{\text {líq }}$ & Thermal diffusivity of liquid PCM $\left[\mathrm{m}^{2} \mathrm{~s}^{-1}\right]$ & $\mu$ & Dynamic viscosity of liquid PCM $\left[\mathrm{kg} \mathrm{m}^{-1} \mathrm{~s}-1\right]$ \\
\hline$\beta$ & Coefficient of thermal expansion of PCM $\left[\mathrm{K}^{-1}\right]$ & $v$ & Kinematic viscosity of liquid PCM $\left[\mathrm{m}^{2} \mathrm{~s}^{-1}\right]$ \\
\hline$\Delta P$ & Pressure drop $[\mathrm{Pa}]$ & $\rho^{\prime}$ & Liquid / solid density ratio of PCM [-] \\
\hline$\Delta T_{\text {máx }}$ & Maximum temperature difference $[\mathrm{K}]$ & Plíq & Liquid state density of PCM $\left[\mathrm{kg} \mathrm{m}^{-3}\right]$ \\
\hline$\varepsilon$ & Effectiveness [-] & $\rho_{\text {sól }}$ & Solid state density of PCM $\left[\mathrm{kg} \mathrm{m}^{-3}\right]$ \\
\hline$\lambda$ & PCM Latent heat of fusion $\left[\mathrm{J} \mathrm{kg}^{-1}\right]$ & $\tau_{a}$ & Dimensionless of time [-] \\
\hline
\end{tabular}

\section{Nomenclature}

Latin alphabet

\begin{tabular}{|c|c|c|c|}
\hline Symbol & Definition & Symbol & Definition \\
\hline $\mathrm{Ar}$ & Number of Archimedes [-] & $\mathrm{NuD}$ & Number of Nusselt abroad[-] \\
\hline$A_{\mathrm{T}}$ & Total area $\left[\mathrm{m}^{2}\right]$ & NTU & Number of transfer units[-] \\
\hline$A_{\mathrm{TC}}$ & Heat Transfer Area $\left[\mathrm{m}^{2}\right]$ & $\operatorname{Pr}$ & Prandtl number [-] \\
\hline$A_{\mathrm{TD}}$ & Total duct area $\left[\mathrm{m}^{2}\right]$ & $\dot{\mathrm{Q}}_{\mathrm{d}}$ & Desired heat flow [W] \\
\hline $\mathrm{C}$ & Constant [-] & $\dot{\mathrm{Q}}_{\text {máx }}$ & Maximum heat flow [W] \\
\hline$C$ p,aire & Specific Heat of Air $\left[\mathrm{J} \mathrm{kg}^{-1} \mathrm{~K}^{-1}\right]$ & $\dot{\mathrm{Q}}_{\text {real }}$ & Real heat flux [W] \\
\hline$C_{\mathrm{p}, \text { líq }}$ & $\begin{array}{l}\text { Specific heat in the liquid state of PCM }[\mathrm{J} \text { kg-1 } \\
\mathrm{K}-1]\end{array}$ & $\mathrm{Ra}$ & Rayleigh number [-] \\
\hline$C_{\mathrm{p}, \mathrm{só} l}$ & $\begin{array}{l}\text { specific heat in the solid state of PCM[J kg-1 } \\
\mathrm{K}-1]\end{array}$ & $\operatorname{Re}$ & Reynolds number [-] \\
\hline$D_{\text {int }}$ & Inner tube diameter $[\mathrm{m}]$ & $r_{\mathrm{ext}}$ & External tube radius [m] \\
\hline$D_{\text {ext }}$ & Outer tube diameter $[\mathrm{m}]$ & $r_{\text {int }}$ & Inner tube radius $[\mathrm{m}]$ \\
\hline$f$ & Friction Factor [-] & Ste & Stefan number [-] \\
\hline Fo & Fourier Number [-] & $t$ & Phase change time $[\mathrm{s}]$ \\
\hline$g$ & Gravity force $\left[\mathrm{m} \mathrm{s}^{-2}\right]$ & $T_{\mathrm{F}}$ & Final air temperature $[\mathrm{K}]$ \\
\hline $\mathrm{Gr}$ & Grashof Number [-] & TPCM & PCM Phase Change Temperature [K] \\
\hline$h_{\text {ext }}$ & External Heat Transfer Coefficient $\left[\mathrm{W} \mathrm{m}^{1} \mathrm{~K}^{-1}\right]$ & $T_{\text {prom }}$ & $\begin{array}{l}\text { Average temperature between initial and } \\
\text { final }[\mathrm{K}]\end{array}$ \\
\hline$h_{\text {int }}$ & Internal heat transfer coefficient $\left[\mathrm{W} \mathrm{m} \mathrm{m}^{-1} \mathrm{~K}^{-1}\right]$ & $T_{\mathrm{s}}$ & Tube surface temperature $[\mathrm{K}]$ \\
\hline$k_{\text {cobre }}$ & Copper thermal conductivity $\left[\mathrm{W} \mathrm{m} \mathrm{m}^{-1} \mathrm{~K}^{-1}\right]$ & $T_{0}$ & Initial air temperature $[\mathrm{K}]$ \\
\hline$k_{\mathrm{PCM}}$ & PCM thermal conductivity[ $\left.\mathrm{W} \mathrm{m}^{-1} \mathrm{~K}^{-1}\right]$ & $u$ & Air speed $\left[\mathrm{m} \mathrm{s}^{-1}\right]$ \\
\hline$m_{\mathrm{PCM}}$ & $\begin{array}{l}\text { Minimum mass of PCM required in the system } \\
{[\mathrm{kg}]}\end{array}$ & $\mathrm{U}$ & $\begin{array}{l}\text { Overall heat transfer coefficient }\left[\mathrm{W} \mathrm{m}^{-1} \mathrm{~K}^{-}\right. \\
\left.{ }^{1}\right]\end{array}$ \\
\hline$m_{\mathrm{t}}$ & Mass of PCM in a tube $[\mathrm{kg}]$ & $u_{\text {máx }}$ & Maximum air speed $\left[\mathrm{m} \mathrm{s}^{-1}\right]$ \\
\hline$m_{\mathrm{a}}$ & Air mass flow $\left[\mathrm{Kg} \mathrm{s}^{-1}\right]$ & $\dot{V}$ & Air flow $\left[\mathrm{m}^{3} \mathrm{~s}^{-1}\right]$ \\
\hline $\mathrm{N}$ & Tubes number [-] & $V \dot{\mathrm{g}}$ & Volumetric expenditure $\left[\mathrm{m}^{3} \mathrm{~s}^{-1}\right]$ \\
\hline$N_{\mathrm{L}}$ & Tubes number in cross section[-] & $V_{\text {tubo }}$ & Tube volume $\left[\mathrm{m}^{3}\right]$ \\
\hline \multirow[t]{2}{*}{$\mathrm{Nu}$} & Nusselt number [-] & $\dot{W}$ vent & Fan Power [W] \\
\hline & & $X$ & Correction factor [-] \\
\hline
\end{tabular}




\section{REFERENCES}

[1] Mustayen A G M B, Mekhilef S and Saidur R Performance study of different solar dryers: A review Renew. Sustain. Energy Rev. vol.34, pp. 463-70, Jun, 2014.

[2] Mekhilef S, Faramarzi S Z, Saidur R and Salam Z "The application of solar technologies for sustainable development of agricultural sector Renew." Sustain. Energy Rev. vol.18, pp. 583-94, Dec, 2013.

[3] Tiwari G N, Bhatia P S, Singh A K and Sutar R F "Design parameters of a shallow bed solar crop dryer with reflector." Energy Conversion. Management. vol. 35, no. 6, pp. 535-42, Jun, 1994.

[4] Karim M A. and Hawlader M N A. "Development of solar air collectors for drying applications." Energy Conversion. Management. vol. 45, no. 3, pp. 329-44., Feb, 2004.

[5] García P, Rincón S and Cuervo S. "Implementación del secador solar de túnel tipo Hohenheim en productos agrícolas, Revisión de literatura." Rev. Puente, vol. 10 no. 1, pp. 7-19. 2016.

[6] Hossain M A. and Bala B K. "Drying of hot chilli using solar tunnel drier." Sol. Energy Rev. vol. 81, pp. 85-92, Jan, 2007.

[7] Bala B K, Morshed M A and Rahman M F. "Solar drying of mushroom using solar tunnel dryer." Int. Sol. food Process. Conf. 1-11. 2009

[8] Hossain M A, Woods J L and Bala B K. "Optimisation of solar tunnel drier for drying of chilli without color loss." Renew. Energy Rev. vol. 30, no. 5, pp. 729-742, Apr, 2005.

[9] Hensel O and Esper A. "The Hohenheim solar tunnel dryer-20 years of succes Food Chain." Int. J. small scale food processing, vol. 31, pp. 2-27, 2001.

[10] Bareiss M and Beer H. "An analytical solution of the heat transfer process during melting of an unfixed solid phase change material inside a horizontal tube "Int. J. Heat Mass Transf. vol. 27,no. 5, pp. 739-46, May, 1984.

[11] Çengel Y. "Heat and mass transfer: A practical approach ed McGraw-Hill." Boston: Boston: McGrawHill, cop. 2007.
[12] Thulukkanam K. "Heat exchanger design handbook ed CRC Press." Boca Raton, Florida: Taylor \& Francis Group, LLC, 2013.

[13] Žukauskas A and Ulinskas R, "Efficiency Parameters for Heat Transfer in Tube Banks." Heat Transf. Eng. vol. 6, no. 1, pp. 19-25. Oct, 1985.

[14] Holman J. "Heat Transfer ed B Stenquist, New York: Raghothaman Srinivasan.” 2010.

[15] Oliver A, Neila F J and García-Santos A. "Clasificación y selección de materiales de cambio de fase según sus características para su aplicación en sistemas de almacenamiento de energía térmica" Mater. Construcción, vol. 62, pp.131-40, Ene-Mar, 2012.

[16] Sari A and Karaipekli A. "Thermal conductivity and latent heat thermal energy storage characteristics of paraffin/expanded graphite composite as phase change material Appl." Therm. Eng. vol. 27, no. 8-9, pp. 12711277, Jun, 2007.

[17] Ukrainczyk N, Kurajica $S$ and Šipušié J. "Thermophysical Comparison of Five Commercial Paraffin Waxes as Latent Heat Storage Materials Chem." Biochem. Eng. Q. vol, 24, no. 22, pp. 129-37, Jul, 2010.

[18] Py X, Olives R and Mauran S. "Paraffin/porousgraphite-matrix composite as a high and constant power thermal storage material" Int. J. Heat Mass Transf. vol. 44, no. 14, pp. 2727-2737, Jul, 2001.

[19] Himran S, Taraka R and Duma A "An Analysis on Thermal Energy Storage in ParaffinWax Using Tube Array on a Shell and Tube Heat Exchanger." Int. J. Mech. Aerospace, Ind. Mechatron. Manuf. Eng. vol. 9, no. 10, pp. 1781-8, 2015.

[20] Prasad A. and Sengupta S. "Nusselt number and melt time correlations for melting inside a horizontal cylinder subjected to an isothermal wall temperature condition. ” J. Sol. Energy Eng. vol. 110, no.4, pp. 340345, Feb, 1988.

[21] Vergara Barrios P. P., Rey López J. M. Osma Pinto G. A. and G.Ordóñez Plata, "Evaluación del potencial solar y eólico del campus central de la Universidad Industrial de Santander y la ciudad de Bucaramanga, Colombia," Rev. UIS Ing., vol. 13, no. 2, pp. 49-57, 2014. 
[22] C A Díaz Gonzalez, López N, Gélvez Arocha O and J L. Chacón Velasco, "Diseño y construcción de una planta piloto para la producción de biodiesel de manera continua," Rev. UIS Ing. vol. 7, no. 1, pp. 105-133, 2008. 